\title{
Restating the Common Law? The Social Action, Responsibility and Heroism Act 2015
}

\author{
James Goudkamp*
}

The Social Action, Responsibility and Heroism Act 2015 entered into force on 13 April 2015. It is too soon for it to have been considered judicially, and it has not yet been subjected to sustained academic analysis. Accordingly, this article considers its impact. In doing so, it situates the Act in its social context and draws attention to the fact that it is part of a large network of statutes that share the same objectives. It is argued, contrary to prevailing views, that parts of the Act change the law. It is also maintained that the Act's reach is not confined to personal injury cases or even to tort cases. It potentially applies far more widely, including to both concurrent and non-concurrent contractual actions that are based on a failure to take reasonable care. In addition to analysing the Act, this article investigates why the legislature might want to restate the common law (which is what the Act does in part), whether replicating the common law is desirable and, if the legislature is bent on restating the common law, how it should go about doing so.

\section{Introduction}

Statutory intervention in tort law, once a rarity, is now commonplace. ${ }^{1}$ The rate of interference seems to be gathering pace, with numerous notable tort law statutes having been

\footnotetext{
Fellow, Keble College, Oxford; Associate Professor, Oxford Law Faculty; Associate Academic Fellow, Inner Temple; Senior Honorary Research Fellow, Faculty of Law, University of Western Australia; Professorial Fellow, School of Law, University of Wollongong; barrister, 7 King's Bench Walk. Early drafts of this article were presented at seminars at the University of Queensland and the Queensland University of Technology. I am grateful to the participants in those seminars for their helpful comments.
} 
enacted since the start of the twenty-first century. An illustration of such a statute is the Compensation Act 2006, ${ }^{2}$ which was passed principally in response to a belief that England and Wales ${ }^{3}$ were in the grip of a damaging compensation culture. ${ }^{4}$ Section 1 of the Act stipulates that in deciding a claim in negligence or breach of statutory duty, judges 'may' consider whether finding for the claimant might ‘(a) prevent a desirable activity from being undertaken at all, to a particular extent or in a particular way, or (b) discourage persons from undertaking functions in connection with a desirable activity.' The Act also provides, in section 2, that '[a]n apology, an offer of treatment or other redress, shall not of itself amount to an admission of negligence or breach of statutory duty'. While these and certain other sections of the Compensation Act merely restate the common law, ${ }^{5}$ the passage of the Act was nonetheless an important development. This is partly because it marked the dawn of a new phase of political interest the tort system.

Another notable tort statute is the Defamation Act 2013. ${ }^{6}$ That Act's overarching purpose is to restrict the circumstances in which liability in defamation arises and thereby diminish

1 The recent surge of legislation in the tort law context is addressed in TT Arvind and J Steele (eds), Tort Law and the Legislature: Common Law, Statute, and the Dynamics of Legal Change (Oxford: Hart Publishing, 2013).

2 The Act and its context are treated comprehensively in A Morris, 'Spiralling or Stabilising? The Compensation Culture and our Propensity to Claim Damages for Personal Injury’ (2007) 70 MLR 349; A Morris, 'The "Compensation Culture" and the Politics of Tort' in TT Arvind and J Steele (eds), Tort Law and the Legislature: Common Law, Statute, and the Dynamics of Legal Change (Oxford: Hart Publishing, 2012) ch 15.

3 Most of the Act does not apply to Scotland: s 17(1).

4 The Hon Bridget Prentice MP (then the Parliamentary Under-Secretary of State for Constitutional Affairs) said during the second reading of the Bill that became the Compensation Act 2006: 'we are determined to tackle practices that might stop normal activities, because people either fear litigation or have become riskaverse. We want to stop frivolous or speculative claims for compensation, and the provisions in the Bill will help us to do just that. They will reassure people who are concerned about being sued that, if they adopt reasonable standards and procedures, they will not be found liable' (HC Deb, 8 June 2006, vol 447, col 419).

5 As to the relationship between s 1 and the common law, see the text accompanying nn 104-109, below. The Act's Explanatory Notes at [18] state that s 2 'reflect[s] the existing law'. This appears to be correct. For example, in Glasgow Corp v Muir [1943] AC 448 (HL) 455 Lord Thankerton said that 'to express regret, ex post facto, that [the defendant] did not take some step which it is now realized would definitely have prevented the accident ... is not an admission in the sense that it can bind the [defendant] ...'.

6 For a conspectus, see A Mullis and A Scott, 'Tilting at Windmills: The Defamation Act 2013' (2014) 77 MLR 1. 
the 'chilling effect' of the law of defamation. ${ }^{7}$ Some notable adjustments made to the law by the Act include the introduction of a 'serious harm' threshold that must be met before a publication can be found to be defamatory, ${ }^{8}$ the abolition of the rule ${ }^{9}$ that each republication triggers a fresh limitation period ${ }^{10}$ and the conferral upon website operators of a new defence. ${ }^{11}$ As most of the Act applies only prospectively, ${ }^{12}$ it is too early to know what its effect will be. ${ }^{13}$ However, it may well have an important impact on the law of defamation. ${ }^{14}$

The latest noteworthy piece of legislation that is of interest to tort scholars is the Social Action, Responsibility and Heroism Act 2015 ('SARAH’). The Bill that became SARAH was hotly debated in Parliament and it received saturation media coverage. ${ }^{15}$ The factors that provoked SARAH's enactment were complex. However, the driving force in this regard, as was the case in relation to the Compensation Act 2006, was a concern that a compensation culture had arisen. The then Lord Chancellor and Secretary of State for Justice, the Rt Hon

7 The Rt Hon Kenneth Clarke MP (then the Lord Chancellor and Secretary of State for Justice) said during the second reading speech of the Defamation Bill 2012 that: 'Our intention is to correct the worst excesses of our current system in which, particularly for the powerful and wealthy, the law makes it rather too easy to menace responsible publishers with libel proceedings. ... We do not want to open the floodgates to endless litigation in our courtrooms by people whose feelings have been hurt but who have not suffered any particular damage' (HC Deb, 12 June 2012, vol 546, col 179). It is contended in one recent article that 'Overall the changes to the law of defamation introduced by the Act will largely favour defendants': D Hooper, K Waite and O Murphy, 'Defamation Act 2013 - what difference will it really make?' (2014) 24 Ent L Rev 199, 206.

8 Section 1(1).

$9 \quad$ Duke of Brunswick v Harmer (1849) 14 QB 185.

10 Section 8(3).

11 Section 5. See also the Defamation (Operators of Websites) Regulations 2013.

12 Section 16(2)-(7).

13 'Whether the Act will prove to have any profound impact on the nature and extent of defamation proceedings remains an open question': A Mullis, R Parkes and G Busuttil (eds), Gatley on Libel and Slander (London: Sweet \& Maxwell, 12th edn, 2013) [1.1]. 'Much will depend on the judicial reception of the Act': Mullis and Scott, above n 6, 108.

14 Cf NJ McBride and R Bagshaw, Tort Law (Harlow: Pearson Education, 5th edn, 2015) p 545 ('the reality is that the Act does not do very much to bring about fundamental change in the law of defamation').

15 See, e.g., 'Chris Grayling vows to "slay health and safety culture"', The Telegraph, 19 June 2014 <http://www.telegraph.co.uk/news/politics/conservative/10978488/Chris-Grayling-vows-to-slay-health-andsafety-culture.html>, accessed 15 June 2016; 'One in three passers-by will not administer first aid because $\begin{array}{llllll}\text { they fear being sued', The Telegraph, } 4 \text { September } 2014 & 4\end{array}$ $<$ http://www.telegraph.co.uk/news/politics/11075274/One-in-three-passers-by-will-not-administer-first-aidbecause-they-fear-being-sued.html>, accessed 15 June 2016; 'Opposition MPs question need for Chris Grayling's social action bill', The Guardian, 12 September 2014 $<$ http://www.theguardian.com/law/2014/sep/12/opposition-mps-question-chris-grayling-sarah-bill-socialaction-responsibility-heroism>, accessed 15 June 2016. 
Chris Grayling MP, who was one of SARAH's sponsors, described SARAH's purpose as follows: ${ }^{16}$

What [SARAH] does ... is drive out spurious claims, deter health and safety jobsworths and help to reassure good, honest and well-meaning citizens that if they act responsibly, do something for the public good or intervene heroically in an emergency, the law will be on their side. Businesses should not be deterred from providing jobs and contributing to our economy by a fear of opportunist litigation and individuals should not be deterred from helping their fellow citizens by a fear that they will somehow put themselves at legal risk.

A government press release stated: ${ }^{17}$

[SARAH] is designed to bring some common sense back to Britain's health and safety culture.

... Changes are being made to counteract the growing perception that people risk being successfully sued if they do something for the common good - like leading a school trip, organising a village fete, clearing snow from a path in front of their home or helping someone in an emergency situation.

This article is concerned with SARAH. There is a need for sustained treatment of the Act given that it has not yet been the subject of judicial elaboration (it is far too early for SARAH to have been considered judicially given its temporal scope, which is discussed below ${ }^{18}$ ). There has also been relatively little academic discussion of SARAH to date. ${ }^{19}$ The primary goal of this article is to analyse the rules for which SARAH provides. In the course of doing

16 HC Deb, 21 July 2014, vol 566, col 1194.

17 C Grayling, Press Release, 2 June 2014, 'Grayling: Law Must Protect Everyday Heroes' $<$ https://www.gov.uk/government/news/grayling-law-must-protect-everyday-heroes>, accessed 15 June 2016.

18 See the text accompanying $n$ 80, below.

19 One short contribution is Editorial, 'Is It a Bird? Is It a Plane? Well it Certainly Isn’t Legislation' (2015) 36 Stat LR v. 
so, two main arguments will be advanced. The first concerns SARAH's impact upon the preexisting law. As will be discussed, it is widely thought that SARAH does not change the law. Many distinguished retired judges, for example, committed themselves to this understanding during debates in the Lords. Similarly, the authors of Clerk \& Lindsell on Torts write that 'It is difficult to avoid the conclusion that [SARAH] ... makes no substantive changes to the law. ${ }^{20}$ This article will reject this position. It will be contended that SARAH makes not insubstantial changes to the law. Second, it will be argued that the significance of SARAH is not confined to personal injury cases or even to tort cases. It has a vastly wider scope, which is a point that seems to have gone unnoticed.

While this article's central aim is to grapple the legislative text that constitutes SARAH, it is necessary to attend to several preliminary matters in order to contextualise the analysis. Thus, SARAH's goals are addressed in Part 2. It is observed in Part 3 that SARAH is one of several related statutes. The significance of this is addressed. SARAH's passage through Parliament is treated in Part 4. These sections are necessary preludes to the analysis of the statutory text, which is provided in Part 5. In Part 6, some remarks are offered about whether it makes sense to 'legislate the common law', which is what the government understood it to be doing, at least in part, in enacting SARAH. The article's main conclusions are summarised in Part 8.

\section{The mischief addressed by SARAH}

SARAH was enacted principally in response to concerns that a compensation culture had arisen. The need to address this culture was a constant refrain in the political dialogue

20 A Dugdale (ed), Clerk \& Lindsell on Torts (London: Sweet \& Maxwell, 21st edn, 2014) [8-174D]. 
regarding SARAH. ${ }^{21}$ The concept of a compensation culture has been insightfully discussed elsewhere. ${ }^{22}$ This article does not recover this ground. Instead, two points that are particularly salient for present purposes will be made. These points are, first, that the government did not have a particularly firm idea of what a compensation culture involves and, second, that the empirical evidence on which the government relied to substantiate its concerns that a compensation culture had arisen was unsatisfactory.

\subsection{An unstable understanding of a compensation culture}

Mr Grayling's second reading speech of the Bill that became SARAH suggests that he may have had at least four different things in mind when he spoke of a compensation culture. First, he may have considered that a compensation culture involves a propensity on the part of society's members to resort with alacrity to litigation, especially in respect of trivial grievances and where the legal merits of the claim are weak. He seemed to channel this meaning of a compensation culture when he said that SARAH is 'focused firmly on ensuring that in future it will be much more difficult for spurious, speculative and opportunistic claims to succeed. ${ }^{23}$ Second, Mr Grayling appeared to understand a compensation culture to involve a tendency on the part of prospective defendants to engage unduly in defensive practices in order to ward off the risk of incurring liability. For example, he said that SARAH was intended to 'counter the fears that are ... putting people off volunteering, and that cause anxiety to small businesses, which worry that they might end up at the wrong end of

21 See the text accompanying nn 16-17, above.

22 Contributions include K Williams, 'State of Fear: Britain’s “Compensation Culture” Reviewed' (2005) LS 499; R Mullender, ‘Negligence Law and Blame Culture: A Critical Response to a Possible Problem’ (2006) 22 PN 2; R Lewis, A Morris and K Oliphant, 'Tort Personal Injury Claims Statistics: Is there a Compensation Culture in the United Kingdom?' (2006) 14 TLJ 158; Morris (2007), above n 2; Morris (2012), above n 2; R Lewis and A Morris, 'Tort Law Culture in the United Kingdom: Image and Reality and Personal Injury Compensation’ (2012) 3 JETL 230; R Lewis, 'Compensation Culture Reviewed: Incentives to Claim and Damages Levels’ [2014] JPIL 209; E Quill and RJ Friel (eds), Damages and Compensation Culture: Comparative Perspectives (Oxford: Hart Publishing, 2016).

23 HC Deb, 21 July 2014, vol 566, col 1190. 
litigation. ${ }^{24}$ Third, a compensation culture may have been perceived an entailing a legal system that was beset by fraudulent claims. Mr Grayling perhaps had this meaning in mind when he said that SARAH 'will root out the insidious and damaging bad practice and unacceptable behaviour on the part of some claimants and their lawyers that has tainted personal injury claims in recent years. ${ }^{, 25}$ Fourth, Mr Grayling might have thought that a compensation culture involved a legal system that was witnessing an escalating number of claims. He placed considerable emphasis on the fact that there had lately been an increase in employers’ liability claims. ${ }^{26}$ The foregoing indicates that Mr Grayling (and the government) appeared not to have a stable idea of what a compensation culture means. Accordingly, it is difficult to see how he (or the government) could have had a clear view of the precise problem that SARAH was designed to address.

\subsection{Inadequate empirical evidence}

In seeking to establish the mischief that SARAH was to address, the then Lord Chancellor said: 'In the last three years alone, figures for personal injury claims registered with the compensation recovery unit show that claims against employers have increased from around 81,000 in 2010-11 to more than 105,000 in 2013-14 - an increase of 30\%.' ${ }^{27}$ This is true but the Lord Chancellor failed to mention two important matters. The first was the fact that the total number of cases registered had barely changed over the three-year period in issue. In 2010-2011, the number of cases registered was 987,381. By 2013-2014, the total was

\footnotetext{
ibid, col 1194.

ibid, col 1191.

ibid, col 1187. See the text accompanying n 27, below.

27 HC Deb, 21 July 2014, vol 566, col 1187. The Compensation Recovery Unit administers a scheme whereby social security payments made to claimants are deducted from compensation awards. Its work is addressed in Lewis, Morris and Oliphant, above n 22, pp 159-161. These scholars write (at 159) that the Compensation Recovery United 'presently holds the most comprehensive data on the number of current personal injury claims.'
} 
1,016,801. ${ }^{28}$ Second, the number of 'settlements' recorded by the Compensation Recovery Unit for employers’ liability cases had fallen, from 98,586 to $96,320 .{ }^{29}$ When understood in the context of these twin points, the statistic regarding claims against employers is considerably less impressive than it is in isolation.

The only other empirical evidence on which the government relied was the report Helping Out: A National Survey of Volunteering and Charitable Giving. ${ }^{30}$ This report presented the results of a joint study conducted by the National Centre for Social Research and the Institute for Volunteering Research. The study was based on data gathered in 2006-2007. 2,156 respondents were interviewed for the 'core sample'. ${ }^{31} 298$ out of 635 (47 per cent) 'non-volunteers, ex-volunteers and occasional volunteers' cited a concern about incurring 'risk/liability' as one of the reasons for not volunteering. ${ }^{32}$ This statistic was seized upon by the government. ${ }^{33}$ However, this was an inadequate foundation on which to have legislated for three reasons. First, out of the 47 per cent of respondents who indicated that concern about incurring 'risk/liability' had deterred them from volunteering only 16 per cent said that this consideration mattered 'a lot'. 31 per cent indicated that it influenced them 'a little'. ${ }^{34}$ The government omitted to mention this important detail. Second, the report is nearly a

28 Compensation Recovery Unit, 'Number of Cases Registered to the CRU' $<$ https://www.gov.uk/government/uploads/system/uploads/attachment_data/file/516771/cases-registeredcru-2014-15.csv/preview>, accessed 15 July 2016.

29 ibid. According to Lewis, Morris and Oliphant, above n 22, 159, the information regarding settlements 'is currently of limited use because there is a considerable element of double-counting of interim and final compensation payments'.

30 N Low, S Butt, A Ellis Paine and J Davis Smith, Helping Out: A National Survey of Volunteering and Charitable Giving (London, Cabinet Office, 2007).

31 ibid, 7.

32 ibid, 68. The same conclusion was reached by the Civil Society Red Tape Task Force in its report Unshackling Good Neighbours (2011), which had been commissioned by the government to investigate disincentives to volunteer. The Task Force declared that fear of being sued was a deterrent (without offering any empirical evidence in support).

33 HC Deb, 21 July 2014, vol 566, col 1192.

34 Low et al, above n 30, 68. 
decade old. Third, and perhaps most significantly, the report was written before the Compensation Act 2006 could have had any effect on the supposed compensation culture. ${ }^{35}$

\section{Statutory intervention related to SARAH}

SARAH is one of several statutes that are designed to address the compensation culture. ${ }^{36}$ Two associated statutes have already been mentioned: the Compensation Act $2006^{37}$ and the

Defamation Act 2013. ${ }^{38}$ However, there are at least four further related statutes. ${ }^{39}$ Each of these will briefly be mentioned. Their significance for the purposes of thinking about SARAH will also be discussed.

The first related statute is the Criminal Justice and Immigration Act 2008. Section 76 is particularly relevant. ${ }^{40}$ It addresses the defences of self-defence and prevention of crime ${ }^{41}$ in the criminal law. ${ }^{42}$ It augments the protection that those defences afford. ${ }^{43}$ That protection

35 The Act was brought into effect gradually. The commencement details, which are complex, are given in Ministry of Justice, Memorandum to the Justice Select Committee: Post-Legislative Assessment of the Compensation Act 2006 (London: The Stationery Office, Cm 8267, 2012) [42]-[53]. It suffices for present purposes to observe that the Act did not come fully into effect until April 2007, i.e., far too late for it to have had an impact on study in issue.

36 A government press release regarding SARAH said that SARAH represents 'ongoing work by the government to tackle the growth of compensation culture': C Grayling, Press Release, 2 June 2014, 'Grayling: Law Must Protect Everyday Heroes'<https://www.gov.uk/government/news/grayling-law-mustprotect-everyday-heroes>, accessed 15 June 2016 (emphasis added).

37 See the text accompanying $\mathrm{n} 5$, above.

38 See the text accompanying nn 6-14, above.

39 The interrelation was made explicit in HC Deb, 21 July 2014, vol 566, cols 1190-1191 (Mr Grayling).

40 Two high-profile cases seemed to galvanise Parliament into legislating in this regard. The first was Tony Martin case: see $R v$ Martin [2001] EWCA Crim 2245; [2003] QB 1. The second involved the Hussain brothers: see $R v$ Hussain [2010] EWCA Crim 94; [2010] 2 Cr App R (S) 60.

41 Section 3(1) of the Criminal Law Act 1967 provides for this defence. That provision states: 'A person may use such force as is reasonable in the circumstances in the prevention of crime, or in effecting or assisting in the lawful arrest of offenders or suspected offenders or of persons unlawfully at large.'

42 Although the latter defence applies to tort claims too (see, e.g., Pollard v Chief Constable of West Yorkshire Police [1999] PIQR P219; Roberts v Chief Constable of Kent [2008] EWCA Civ 1588; [2009] Po LR 8; McDonnell $v$ The Commissioner of Police for the Metropolis [2015] EWCA Civ 573), s 76 operates only in the criminal context (see s 76(1)).

43 See, esp, s 76(5A), which stipulates: 'In a householder case, the degree of force used by D is not to be regarded as having been reasonable in the circumstances as D believed them to be if it was grossly disproportionate in those circumstances.' For discussion, see $R$ (Collins) $v$ Secretary of State for Justice [2016] EWHC 33 (Admin); [2016] 1 Cr App R 25. 
was further and considerably enhanced by a 2013 amendment to section $76 .{ }^{44}$ Section 76 is of interest because it and the amendments to it were enacted with a view to insulating from liability 'have-a-go heroes' who exercise defensive force save in fairly extreme cases, such as where 'grossly disproportionate' force is used. ${ }^{45}$ The link between section 76 and SARAH is obvious.

The second statute associated with SARAH is the Enterprise and Regulatory Reform Act 2013. Its most interesting provision for current purposes is section $69 .{ }^{46}$ That provision amended section 47 of the Health and Safety at Work etc. Act 1974. The effect of the amendment is to render, contrary to the position that previously obtained, 'breach[es] of a duty imposed by a statutory instrument containing ... health and safely regulations, ${ }^{47}$ unactionable unless the instrument concerned provides otherwise. This change to the law was precipitated, at least partially, by Lord Young's report Common Sense, Common Safety, ${ }^{48}$ which had been commissioned by the Prime Minister with a view to addressing 'a damaging compensation culture'. ${ }^{49}$ In his report, Lord Young recommended that the 1974 Act be reviewed in order to ensure that health and safety regulations 'reflect a proportionate response to risk' ${ }^{50}$ Section 69 flowed from this recommendation. ${ }^{51}$ It is intimately associated with SARAH.

44 Crime and Courts Act 2013, s 43.

45 For discussion, see S Miller, ““Grossly disproportionate”: home owners’ legal licence to kill’ [2013] J Crim L 299.

46 Treatments of s 69 are offered in N Tompkins, 'Civil health and safety law after the Enterprise and Regulatory Reform Act 2013' [2013] JPIL 203; P Limb and J Cox, 'Section 69 of the Enterprise and Regulatory Reform Act 2013 - plus ca change?' [2014] JPIL 1; A Roy, 'Without a safety net: litigating employers' liability claims after the Enterprise Act' [2015] JPIL 15.

47 Section 69(2).

48 Lord Young, Common Sense, Common Safety (London: HM Government, 2010).

49 ibid, 5.

50 ibid, 39.

51 See Department for Work and Pensions, A Final Report on the Implementation of Health and Safety Reforms (2015) 12. 
Third, SARAH is linked with the implementation of certain of the proposals made in Sir Rupert Jackson's Review of Civil Litigation Costs. ${ }^{52}$ Myriad changes to the law were made in this regard by the Legal Aid, Sentencing and Punishment of Offenders Act 2012. That statute, inter alia, rendered both success fees payable under conditional fee agreements and after-the-event insurance premiums irrecoverable as costs. ${ }^{53}$ In personal injury cases, it also reduced the maximum success fee chargeable from 100 per cent to 25 per cent ${ }^{54}$ and prohibited the payment of referral fees. ${ }^{55}$ These changes were touted by the government as steps taken 'to remove the perception of a compensation culture. ${ }^{\text {56 }}$

A final statute that is deserving of mention is the Criminal Justice and Courts Act 2015. This Act contains several provisions that are animated by a concern regarding fraudulent personal injury claims. Section 57 provides that if the court is satisfied on the civil standard that the claimant, despite having an entitlement to damages, 'has been fundamentally dishonest', ${ }^{57}$ the claim must be dismissed. The provision is subject to a safety-value discretion, which is triggered where the court is satisfied that dismissal of the claim would cause 'substantial injustice'. ${ }^{58}$ Section 58 is also of interest. It prohibits lawyers from offering inducements to commence personal injury proceedings. ${ }^{59}$ This provision supplements similar rules that prevent claims management companies from offering inducements to litigate. ${ }^{60}$ Again, these provisions are closely associated with SARAH's.

52 R Jackson, Review of Litigation Costs, Final Report (London: The Stationary Office, 2010). For critical assessment, see A Zuckerman, 'The Jackson Final Report on Costs-Plastering the Cracks to Shore Up a Dysfunctional System’ (2010) 29 CJQ 263; Working Group of Civil Litigation Costs, On a Slippery Slope: A Response to the Jackson Report (Institute for European Tort Law, 2011); R Lewis, 'Litigation Costs and Before-the-Event Insurance: The Key to Access to Justice?' (2011) MLR 272.

53 Sections 44(4), 46(1).

54 Section 44(2); Conditional Fee Agreements Order 2013 (No 689) r 5(1)(a).

55 Section 56.

56 Ministry of Justice, Policy Paper: 2010 to 2015 government policy: civil justice reform (2015), appendix 2.

57 Section 57(1)(b).

58 Section $57(2)$.

59 Section 58 was inspired by a recommendation made by Lord Young in his report: Lord Young, above n 56, annex $\mathrm{H}$.

60 Ministry of Justice, Claims Management Services Regulation, Conduct of Authorised Persons Rules 2014, r 6(b) ('In soliciting business through advertising, marketing and other means a business must: ... b) Not 
The foregoing discussion reveals that SARAH is part of a package of statutes that is intended to address the compensation culture. This statutory context is important for the purposes of coming to grips with SARAH. Given the close connections between SARAH and these other statutes, the latter conceivably cast light on how SARAH should be construed (and vice versa). As Lord Mansfield CJ explained in Timmins v Rowlison, 'Statutes in pari materia are to be all taken as one system to suppress the mischief' ${ }^{61}$

\section{SARAH's Passage through Parliament}

SARAH's gestation period was unusually rapid. It was revealed in the 2014 Queen's Speech that 'A bill [would] be brought forward to provide that where a person acts heroically, responsibly or for the benefit of others, this will be taken into account by the courts. ${ }^{62}$ Just eight days later (12 June 2014), the Bill that became SARAH was introduced in the Commons. The ping pong stage was completed on 2 February 2015 and the Bill received Royal Assent on 12 February 2015. SARAH was brought into force on 13 April $2015 .{ }^{63}$ The usual consultation process was not conducted and no input was sought from the Law Commission. ${ }^{64}$ The unusual rapidity with which the legislative process was carried out suggests that the government considered that SARAH was especially important.

SARAH was trenchantly criticised during the debates, especially in the Lords. Lord Pannick remarked said that he could not 'remember a legislative proposal that has been

offer any cash payment or a similar benefit as an inducement for making a claim.'). These rules were made pursuant to cl 22 of the Compensation (Claims Management Services) Regulations 2006 (SI 3322/2006).

61 (1764) $1 \mathrm{Wm} \mathrm{Bl} \mathrm{533,} \mathrm{534;} 96$ ER 309, 309.

62 <https://www.gov.uk/government/speeches/queens-speech-2014>, accessed 15 June 2016.

63 The Social Action, Responsibility and Heroism Act 2015 (Commencement and Transitional Provision) Regulations 2015, cl 2.

64 As Lord Walker of Gestingthorpe observed, the Law Commission had been 'bypassed completely': HL Deb, 15 December 2014, vol 589, col 20. His Lordship considered that this came 'close to a constitutional issue’: ibid. 
the subject of more sustained ridicule and derision. ${ }^{65}$ Neither, he said, could he 'remember a more pointless, indeed fatuous, piece of legislation' ${ }^{66}$ Numerous retired Law Lords launched withering attacks on SARAH. Lord Walker of Gestingthorpe remarked that he was 'genuinely shocked by the low standard of draftsmanship in the Bill-presumably it was prepared by government lawyers.' ${ }^{67}$ Lord Hope of Craighead derided SARAH as 'halfbaked'. ${ }^{68}$ Lord Brown of Eaton-under-Heywood described SARAH as being 'objectionable', ${ }^{9}$ 'absurd ${ }^{70}$ and its enactment 'a waste of legislative time'. ${ }^{71}$ Lord Woolf referred to certain provisions of SARAH as 'very worrying' ${ }^{72}$ Lord Lloyd of Berwick was most scathing of all. He said that SARAH 'was never properly thought out in the first place' and that one of its provisions 'looked like a clause drafted on the back of an envelope. ${ }^{73}$ His overall assessment was that SARAH was 'inherently ridiculous' ${ }^{74}$ and 'so defective ... that the only feasible amendment is to take each of [its operative] clauses in turn and remove [them] ...' ${ }^{75}$ SARAH, he predicted, '[would] be treated with derision when it comes before the courts'. ${ }^{76}$ Notwithstanding these complaints, SARAH was only lightly amended in the Lords, on both instances by the government (the amendments are mentioned below ${ }^{77}$ ).

65 HL Deb, 15 December 2014, vol 589, col 16.

66 ibid.

67 ibid, col 45.

ibid, col 19

ibid, col 21.

ibid, col 33.

HL Deb, 4 November 2014, vol 587, col 1558.

HL Deb, 15 December 2014, vol 589, col 33.

ibid, col 44.

44 ibid.

HL Deb, 4 November 2014, vol 587, col 1551.

HL Deb, 15 December 2014, vol 589, col 15.

77 See the text accompanying nn 110, 125, below. 


\section{Analysis of the legislative text}

In stark contrast to many contemporary statutes, SARAH is remarkably short. ${ }^{78}$ It contains just five sections. Section 1 specifies SARAH's scope. Sections 2-4 are the Act's operative provisions. Each of these sections is just a single sentence in length. Section 5 concerns SARAH's jurisdictional ambit (the Act applies only to England and Wales ${ }^{79}$ ), commencement and transitional arrangements. There is no section that sets out defined terms. SARAH has not yet been the subject of judicial exposition (at least not in the shape of any electronically available decision). This is unsurprising as SARAH applies only to acts or omissions giving rise to a relevant claim occurring on or after 13 April $2015 .^{80}$

\subsection{When does SARAH apply?}

Section 1 of SARAH stipulates that the Act applies when a court 'in considering a claim that a person was negligent or in breach of statutory duty, is determining the steps that the person was required to take to meet a standard of care.' This provision raises the following important questions. First, does SARAH apply when contributory negligence is pleaded? Second, what is the relationship between SARAH and the doctrines of vicarious liability and identification? Third, to what causes of action does SARAH extend? These questions will be addressed seriatim.

It is strongly arguable that SARAH applies not only to claims that the defendant was negligent and acted in breach of statutory duty but also to allegations of contributory

78 SARAH is not the shortest statute that has ever been enacted. The statute that contains the fewest operative words is the Parliament (Qualification of Women) Act 1918. That Act contains just 27 operative words. SARAH contains 106.

79 Section 5(1).

80 The Social Action, Responsibility and Heroism Act 2015 (Commencement and Transitional Provision) Regulations 2015, cl 3. 
negligence. Section 1 refers to a 'person' rather than to the 'defendant'. This suggests that section 1 speaks to both parties. Furthermore, section 1 fairly can be understood as referring to negligence in the sense of conduct that falls short of the standard of care that the reasonable person would have achieved rather than to the cause of action in negligence. This interpretation is supported by the reference to 'a claim' that a person was negligent or breach a statutory duty rather than to, for example, 'an action based upon' negligence or a breach of statutory duty. The words 'breach of statutory duty' do not suggest that SARAH is concerned only with the defendant's conduct (and hence not with contributory negligence) since a breach of statutory duty by the claimant can constitute contributory negligence. ${ }^{81}$ However, there is at least one consideration that suggests that SARAH might not apply to allegations of contributory negligence. Section 3 (which is discussed below) is concerned with whether 'the person ... demonstrated a predominantly responsible approach towards protecting the safety or other interests of others' ${ }^{82}$ This is significant because contributory negligence entails selfregarding fault. ${ }^{83}$ It is irrelevant to the issue of contributory negligence that the claimant took care (or failed to take care) of individuals other than himself. ${ }^{84}$ Hence, section 3 could not apply to allegations of contributory negligence, and it might be thought that this should have a bearing on how section 1 should be construed. Why, it might be asked, would section 1 extend SARAH to allegations of contributory negligence if one of the Act's three operative sections cannot apply to contributory negligence? Despite this consideration, on balance it

81 This is clear from s 4 of the Law Reform (Contributory Negligence) Act 1945. That provision defines 'fault' for the purposes of s 1 of that Act as 'negligence, breach of statutory duty or other act or omission which gives rise to a liability in tort or would, apart from this Act, give rise to the defence of contributory negligence.' See, further, Pritchard v Co-operative Group Ltd [2011] EWCA Civ 329; [2012] QB 320, 330 [30]. Arguably, the very fact a breach of statutory duty can amount to contributory negligence explains why s 1 of SARAH refers to breach of statutory duty. That reference would otherwise be puzzling given the shift in the law regarding actions for breach of statutory duty discussed above: see the text accompanying nn 4651.

82 Emphasis added.

83 'Contributory negligence is a man's carelessness in looking after his own safety': Froom v Butcher [1976] QB 286 (CA) 291 (Lord Denning MR) (emphasis in original).

84 But see Sabir v Osei-Kwabena [2015] EWCA Civ 1213; [2016] RTR 9, [15]-[16] where Tomlinson LJ, speaking for the Court, placed weigh on the fact that the claimant did not risk the defendant's safety in considering an appeal regarding the apportionment of damages. 
appears likely that SARAH (save for section 3) extends to allegations of contributory negligence. If this is right, to the extent that SARAH makes it harder for an allegation of defective behaviour to stick, the SARAH might sometimes increase awards of compensation.

A difficult issue concerns the interplay between SARAH and the doctrines of vicarious liability and identification. Suppose that D employs $\mathrm{T}$ who injures $\mathrm{C}$ in the course of his employment. Imagine, too, that $\mathrm{D}$ is not directly liable to $\mathrm{C}$ but liable only vicariously. If C proceeds against D only (as would occur in practice) will SARAH apply? Exactly the same puzzle arises where a defendant pleads contributory negligence on the basis of the conduct of a person with whom the claimant is identified (assuming, if as has just been argued, that SARAH applies to allegations of contributory negligence). It seems clear that SARAH would be engaged in both of these situations. To take the doctrine of vicarious liability, even where a claim is brought on the basis of that doctrine, the court is still considering 'a claim that a person ... was negligent or in breach of statutory duty’.

Finally, to what causes of action does SARAH apply? Three important points need to be made in answer to this question. The first is that SARAH is not confined to personal injury cases. Despite the concentration on those cases in the Parliamentary debates, ${ }^{85}$ SARAH applies regardless of the type of damage suffered. The second point is that, in so far as tortious actions are concerned, it is unlikely that SARAH extends other than to actions in negligence and breach of statutory duty. This is because there are no other torts that involve a claim that a person was 'that a person was negligent or in breach of statutory duty'. Third, it seems that SARAH applies to contractual claims that are based on a failure to take reasonable care, whether or not liability arises concurrently in tort. Lord Faulks, who was SARAH's sponsor in the House of Lords, doubted that SARAH applies to proceedings for breach of

85 See, e.g., the quotations accompanying nn 16, 27, above. 
contract. ${ }^{86}$ However, this doubt is unjustified as none of the language in the Act is specific to the law of torts. It is not only the government that has overlooked the fact that SARAH likely applies to contractual claims that are based on negligence. Contract law scholars have too. The latest editions of Chitty on Contracts ${ }^{87}$ and Treitel: The Law of Contract, ${ }^{88}$ for example, both of which were published after SARAH was enacted, do not refer to SARAH.

\subsection{Social action}

Section 2 provides: 'The court must have regard to whether the alleged negligence or breach of statutory duty occurred when the person was acting for the benefit of society or any of its members.' The then Lord Chancellor said the following about section 2 during the Parliamentary debates: ${ }^{89}$

I want people to feel confident about participating in activities that benefit others without worrying about what might happen if, despite their best efforts, something goes wrong and thy find themselves defending a negligence claim. [Section] 2, on social action, provides valuable reassurance that if that does happen, the court, when reaching a decision on liability, will take careful and thorough account of the contexts of the defendant's actions and the fact that he or she was acting for the benefit of society.

The following eight issues arise in connection with section 2. First, when the court finds that a 'person was acting for the benefit of society or any of its members', how much weight must it give to that fact? Section 2 merely requires that the court have 'regard' to it.

${ }^{86}$ Lord Faulks said that he 'd[id] not see any reference to breach of contract [in SARAH's preamble]': HL Deb, 15 December 2014, vol 589, col 37.

87 H Beale (ed), Chitty on Contracts (London: Sweet \& Maxwell, 32nd edn, 2015).

88 E Peel, Treitel: The Law of Contract (London: Sweet \& Maxwell, 14th edn, 2015).

89 HC Deb, 21 July 2014, vol 566, cols 1192-1193. 
Presumably, this only requires the court to take cognisance of it. It would seem that the fact that a 'person was acting for the benefit of society or any of its members' need not be given any particular weight or, indeed, any weight at all. Lord Faulks seemed to confirm as much. He said: 'It will be for the court to determine whether a person was acting for the benefit of society and, if so, what weight it should give to that factor in all the circumstances of the individual case. ${ }^{90}$

Second, are artificial legal persons entitled to invoke section 2? The answer to this question depends on the construction of the word 'person'. Lord Walker of Gestingthorpe observed that the fact that SARAH refers both to 'the person' and 'an individual' (in section 4, which discussed below) suggests that the term 'person' is used in contradistinction to 'individual', with the result that artificial legal entities count as 'persons'. ${ }^{91}$

Third, is section 2 is limited to 'persons' who provide voluntary services? One of SARAH's key purposes is to promote volunteering. As was observed earlier, the government was eager to ensure that the threat of litigation did not discourage people from providing gratuitous services. ${ }^{92}$ However, there is no reason to think that section 2 applies only to volunteers. Virtually anyone could stand to benefit from section 2, including businesses that are carried on for a profit. ${ }^{93}$ Lord Faulks effectively indicated as much when he said: ${ }^{94}$

90 HL Deb, 15 December 2014, vol 589, col 24.

91 ibid, col 46.

92 See the quotations accompanying nn 16-17, 24, 33, above. There is a link here with the Coalition Government's 'Big Society' programme pursuant to which steps would be taken 'to support and encourage social responsibility, volunteering and philanthropy, and make it easier for people to come together to improve their communities and help one another': The Coalition: Our Programme for Government (London: Cabinet Office, 2010) 29. Paragraph 6 of SARAH's Explanatory Notes provides: 'The Act forms part of the Coalition Government's wider programme to encourage participation in civil society and the Coalition Agreement contained a specific commitment to "take a range of measures to encourage volunteering and involvement in social action”'. For discussion of the 'Big Society' dogma, see MJ Smith, 'From Big Government to Big Society: Changing the State-Society Balance’ (2010) 63 Parliamentary Aff 818.

93 This possibility is explored in A Okoye, 'The UK Social Action, Responsibility and Heroism (SARAH) Act 2015 and Corporate Social Responsibility (CSR): Potential Connections’ (2015) 26 ICCLR 373.

94 HL Deb, 15 December 2014, vol 589, cols 23-24. 
Although the primary concern underlying [section 2] is to ensure that voluntary activities are encouraged and supported, we see no reason to restrict its application to such cases. In common with other [sections of SARAH, section 2] is therefore broadly drafted so that it will apply in a wide range of situations where people act for the benefit of others, whether they do so on a voluntary basis or in a paid capacity. ... [T]his could, for example, include organised charitable activities such as running a village fete, or informal individual activities such as helping an elderly neighbour with their shopping. It could also cover workers such as teachers, doctors, and emergency services who act for the benefit of society as part of their jobs.

Clerk \& Lindsell on Torts takes the position that a company that 'deliver[s] goods to a supermarket' or that is engaged in 'the commercial provision of leisure activities' ${ }^{95}$ is within the scope of section 2. The authors add that '[o]n a broad interpretation the only defendants who would not fall within s.2 are those engaged in positively anti-social activities (such as criminals) and private individuals acting for their own purposes (such as a private motorist wanting to get from A to B)., 96

Fourth, what relationship is needed between the impugned conduct and the benefit to trigger section 2? It seems that it is unnecessary that the conduct concerned actually benefit society or anyone in particular. It will be enough that the person was 'acting for the benefit of society or any of its members'. The legislation does not insist that a concrete benefit was in fact conferred. Would conduct that conferred benefits by happenstance be sufficient? Presumably, it would not. A person who confers benefits other than by design is not 'acting' for the benefit of the beneficiary. The person in question must, it would seem, at least be striving to confer the benefits in issue. ${ }^{97}$ It is unclear whether it would be enough that the

Dugdale, above n 20, [8-174A].

96 ibid.

97 It is suggested in Clerk \& Lindsell on Torts that there must be 'benevolent intentions': ibid. 
person concerned mistakenly thought that his conduct would confer benefits. Section 2 is silent on this point.

Fifth, what types of benefits qualify as 'benefits' for the purposes of section 2? Similarly, how substantial does some advantage need to be before it is a 'benefit'? Section 2 identifies neither the nature nor the size of the 'benefit' that the person in issue must be acting to confer. The absence of any qualifying words in section 2 suggests that a benefit of literally any variety and magnitude will suffice. A minor benefit presumably will count, although some type of de minimis threshold might be read into section 2 in this regard.

The sixth point concerns the burdens of pleading and proof. On its face, section 2 does not place any onus in this regard on anyone. It seems that, contrary to the principle of autonomy, ${ }^{98}$ the court must take into account proprio motu the fact that one of the parties was acting for the benefit of society or any of its members. As a practical matter, however, litigants likely will seek to invoke section 2 (just as it is commonplace for defendants to rely on, for example, the illegality doctrine even though the court is required to consider on its own accord whether that doctrine is engaged ${ }^{99}$ ).

Seventh, is the party who seeks to rely on section 2 included in 'any of [society's] members'? If this question is answered affirmatively, the court must take account of the fact that the party was acting for his or her own benefit, in which case section 2 clearly breaks with the common law. While it has long been established that the social value of the activity that gives rise to a risk is relevant to whether negligence exists, ${ }^{100}$ the common law does not permit a party to resist an allegation of negligence on the ground that he cut corners only in

98 As to this principle, see A Zuckerman, Zuckerman on Civil Procedure: Principles of Practice (London: Sweet \& Maxwell, 3rd edn, 2013) [11.9]-[11.20].

99 'It is because the public has its own interest in conduct giving rise to the illegality defence that the judge may be bound to take the point of his own motion, contrary to the ordinary principle in adversarial litigation': Les Laboratoires Servier v Apotex Inc [2014] UKSC 55; [2015] AC 430, 445 [23] (Lord Sumption JSC). Cf Zuckerman, above n 98, [11.10].

100 Tomlinson v Gongleton Borough Council [2003] UKHL 47; [2004] 1 AC 46, 82 [34] (Lord Hoffmann). 
order to maximise his or her own profits. ${ }^{101}$ How, then, are the relevant words in section 2 to be construed? Obviously, these words - 'any of [society's] members' - naturally include both parties. However, this construction was not envisaged by SARAH's architects. During the Parliamentary debates, Mr Shailesh Vara MP (the Parliamentary Under-Secretary of State for Justice) said: 'The provision on social action could cover anyone who acts for the benefit of others on a voluntary or in a paid capacity.' ${ }^{102}$ He opined that 'purely self-interested or selfcentred actions will not fall within its scope. ${ }^{103}$ However, there is nothing in SARAH that supports this last proposition.

Eighth, how does section 2 of SARAH relate to section 1 of the Compensation Act 2006? The latter section provides that, where a court is considering a claim in negligence or breach of statutory duty, it may, in determining whether the defendant should have taken particular steps to meet a standard of care, 'have regard to whether a requirement to take those steps might (a) prevent a desirable activity from being undertaken at all, to a particular extent or in a particular way, or (b) discourage persons from undertaking functions in connection with a desirable activity. ${ }^{104}$ Section 1 has been mentioned infrequently by the courts. ${ }^{105}$ The prevailing view is that it does not alter the common law. ${ }^{106}$ Are section 2 of SARAH and section 1 of the Compensation Act different in any material respect? One difference is that the latter speaks of a 'desirable activity' whereas the former refers to acting for the 'benefit of

\footnotetext{
101 Cf Latimer v AEC Ld [1953] AC 643 (HL) 653.

102 PBC Deb, 9 September 2014, col 71.

103 ibid.

104 Section 1 of the Compensation Act was inspired by nearly identical statutory provisions that exist in most Australian jurisdictions: see, e.g., Civil Liability Act 2002 (NSW), s 5B(2)(d).

105 It was mentioned in passing in Hopps $v$ Mott Macdonald Ltd [2009] EWHC 1881 (QB), [91]-[93]; Scout Association v Barnes [2010] EWCA Civ 1476, [34]; Reynolds v Strutt \& Parker LLP [2011] EWHC 2263 (QB), [47]; Uren v Corporate Leisure (UK) Ltd [2011] EWCA Civ 66; (2011) 108(7) LSG 16, [13]; Sutton v Syston Rugby Football Club Ltd [2011] EWCA Civ 1182, [13]; Wilkin-Shaw v Fuller [2012] EWHC 1777 (QB); [2012] ELR 575, [41]-[46]; Uren v Corporate Leisure (UK) Ltd [2013] EWHC 353 (QB), [75]; McErlean $v$ The Right Reverend Monsignor Ambrose [2014] NIQB 1, [12]; Humphrey v Aegis Defence Services Ltd [2014] EWHC 989 (QB), [112]-[113].

106 E.g., in Scout Association v Barnes [2010] EWCA Civ 1476 [34] Jackson LJ said that 'the principle ... now enshrined in section $1 \ldots$ has always been part of the common law.' Annette Morris writes that s 1 is 'a statutory restatement of one aspect of the common law relating to breach of duty': Morris (2007), above n 2, 368.
} 
society'. However, it is not clear what the difference is, if any, between a 'desirable activity' and a 'beneficial activity'. This consideration (among others) prompted Lord Lloyd of Berwick to move an amendment to omit section 2 from the Bill that became SARAH. Lord Lloyd argued: ${ }^{107}$

\begin{abstract}
'The whole purpose of [section 1 of the Compensation Act 2006] was to encourage people to undertake what the section calls, "desirable activities". The whole purpose of Clause 2 of the [SARAH] Bill is to encourage people to act, "for the benefit of society". Those are two ways of saying exactly the same thing. Nobody has yet been able to detect any difference between them.’
\end{abstract}

This proposal to amend the Bill was rejected. Pace Lord Lloyd and others who believe that section 2 of SARAH merely mirrors section 1 of the Compensation Act, ${ }^{108}$ there are in fact significant differences between the two sections. For one thing, section 2 of SARAH is cast in mandatory terms ('must') whereas the section 1 of the Compensation Act uses permissive language ('may'). Another difference concerns third parties. Section 1 of the Compensation Act is concerned with the deterrent effect that finding liability might have on persons generally in terms of their participation in 'desirable activities'. Conversely, section 2 of SARAH is significantly more confined. It is concerned only with whether the relevant person 'was acting for the benefit of society or any of its members.' A final difference is that section 1 of the Compensation Act is concerned only with defendants whereas section 2 of SARAH is, by virtue of the scope given to SARAH by section $1,{ }^{109}$ sensitive to the behaviour

\footnotetext{
107 HL Deb, 15 December 2014, vol 589, col 1572.

108 It is said in Clerk \& Lindsell on Tort that: 'Given that the courts already take into account the utility of the defendant's activity when determining whether he has taken an unreasonable risk ... it is difficult to see what s.2 adds to the common law' (Dugdale, above n 20, [8.174A]).

109 See the text accompanying nn 81-84, above.
} 
of claimants too. In view of these differences, the suggestion that the two sections cover identical terrain is mistaken.

\subsection{Responsibility}

Section 3 provides that 'the court must have regard to whether the person, in carrying out the activity in the course of which the alleged negligence or breach of statutory duty occurred, demonstrated a predominantly responsible approach towards protecting the safety or other interests of others. ${ }^{110}$ The then Lord Chancellor said that section 3:111

has a particular importance in ensuring we provide proper protection for small businesses. I have talked to countless business groups and employers who tell me how the compensation culture is tying their business in knots. Employers might do the right thing and put in place sensible procedures, but then someone does something daft and the employer still finds themselves facing a damages claim.

The government considered that section 3 'changes the law'. ${ }^{112}$

Is section 3 a substantive rule or a rule of evidence? Expressed differently, does section 3 go to the test for negligence (and contributory negligence) and breach of statutory duty or does it alters the evidence that the court can consider in applying those tests. If section 3 operates substantively such it adds to the list of issues that the court must weigh in deciding liability, section 3 changes the common law. For example, it is well established that, at common law, in determining an allegation that a given act or omission was negligent (or constitutes contributory negligence), the court must determine whether that act or omission

\footnotetext{
110 The Bill originally used the word 'generally' instead of 'predominantly'.

111 HC Deb, 21 July 2014, vol 566, col 1191.

112 PBC Deb, 9 September 2014, col 62 (Mr Vara).
} 
was negligent. ${ }^{113}$ The court does not ask, instead, whether a wider course of conduct of which the allegedly negligent act or omission is a part was negligent. ${ }^{114}$ Thus, if a motorist who caused an accident is sued in negligence, it is not a valid answer at common law for the motorist to assert that he or she usually drove carefully and that the mistake which led to the claimant being injured was therefore an isolated error. The question for the court is whether the mistake that resulted in damage was a negligent one.

Perhaps, however, section 3 operates only as a rule of evidence. So understood, section 3 merely renders admissible the track record (apparently, whether or not good or bad) of the person in issue for the purposes of deciding whether the person was in fact negligent or in breach of statutory duty on the occasion in issue. When interpreted in this way, does section 3 change the law? At common law, while evidence of a good track record is admissible in civil cases, ${ }^{115}$ evidence of a bad record is not ${ }^{116}$ unless it amounts to is 'similar fact evidence', ${ }^{117}$ and even then the judge has a discretion to exclude it. ${ }^{118}$ It is, accordingly, clear that section 3 also breaks with the common law if it is understood as an evidential rule. In so far as a good track record is concerned, section 3 changes the law in that it compels the court to consider that record whereas in the past it fell to the party who wished to put evidence of a good record in issue to persuade the court that the evidence should be admitted. The change in the law wrought by section 3 is more substantial in relation to evidence of a bad track record. As has been observed, the starting position is that evidence of such a record was inadmissible.

113 The significance of this rule for the operation of the tort system is treated perceptively in PS Atiyah, The Damages Lottery (Oxford: Hart Publishing, 1997) 34.

114 'When considering whether a defendant was in breach of duty the issue is whether the act(s) or omission(s) which caused the claimant's damage fell below the standard of reasonable care in the circumstances. It is not, and never has been, whether a defendant is "predominantly" or generally careful' (Dugdale, above n 95, [8-174B]).

115 For example, in Cavanagh v Ulster Weaving Co Ltd [1960] AC 145 (HL) 158 Viscount Simons LC said: 'It would, I think, be unfortunate if an employer who has adopted a practice, system or set-up, call it what you will, which has been widely used without complaint, could not rely on it as at least a prima facie defence to an action for negligence ...'. See also at 161-163 (Lord Tucker); Crafter $v$ The Metropolitan Railway Co 300 (1865-66) LR 1 CP 300, 303

116 See, generally, H Malek (ed) Phipson on Evidence (London: Sweet \& Maxwell, 18th edn, 2015) [7-30]; C Tapper, Cross \& Tapper on Evidence (Oxford: Oxford University Press, 12th edn, 2010) p 369.

117 Laughton v Shalaby [2014] EWCA Civ 1450; [2015] PIQR P6, [21].

118 ibid, [22]. 
Section 3 alters the common law in making it mandatory for the court to consider a poor track record.

Irrespective of whether or not section 3 is understood as a substantive or evidential rule, three points deserve to be mentioned about section 3. The first concerns how much of a person's life must be considered by the court in determining whether that person's approach was 'predominantly responsible'. For example, in the case of a motorist, would the court be required to consider how well the motorist drove earlier in the same day and, perhaps, week, month or year? Relatedly, if damage is caused while a person was engaged in activity $\mathrm{X}$, is the court required to consider the approach towards protecting the safety or interests of others' of that person only in relation to activity $\mathrm{X}$, or does section 3 also oblige the court to address the person's approach in relation to activity $\mathrm{Y}$ too? The former would seem to be the better construction. Section 3 states that the court 'must have regard to whether the person, in carrying out the activity in the course of which the alleged negligence or breach of statutory duty occurred demonstrated a predominantly responsible approach towards protecting the safety or other interests of others. ${ }^{119}$

The next point is that section 3 threatens to have a substantial impact on the civil litigation process. Lord Woolf observed that 'If one is going to look at the person's general behaviour in deciding actions for tort, these are going to take a lot longer to resolve than they have hitherto'. ${ }^{120}$ Lord Faulks retorted that '[w]hat [section 3] ... would not involve [is] ... going through [the defendant's] safety record for the previous 10 years ...' ${ }^{121}$ However, section 3 contains no limiting words in this regard. Lord Woolf's point therefore remains valid, and it identifies a reason to doubt seriously the sense of section 3 .

The final point relates to the fact that section 3 speaks of a 'responsible' approach to the safety and interests of others. The legislature did not use used the much more familiar word

\footnotetext{
119 Emphasis added.

120 HL Deb, 15 December 2014, vol 589, col 33.

121 ibid, col 36.
} 
'reasonable'. It is likely that argument will break out as to whether the word 'responsible' is used in section 3 as a synonym for 'reasonable'. The rhetorical question will doubtlessly be posed, why did the legislature, if it intended 'responsible' to mean 'reasonable', did it not use the latter term. It is worth recalling that the word 'responsible' featured in the test for the now extinct Reynolds ${ }^{122}$ privilege. ${ }^{123}$ The courts never made it particularly clear whether the word 'responsible' in this context meant' reasonable'. ${ }^{124}$

\subsection{Heroism}

Section 4 of SARAH states: 'The court must have regard to whether the alleged negligence or breach of statutory duty occurred when the person was acting heroically by intervening in an emergency to assist an individual in danger.' ${ }^{125}$ The then Lord Chancellor said of section $4:^{126}$

Unfortunately, it is often the case that people are unwilling to intervene to help in emergencies, and may stand by and do nothing when somebody collapses on the street, for example, because they are worried about the legal position if they do try to help and something goes wrong. ... [Section] 4 therefore addresses these concerns by giving reassurance that heroic behaviour in emergencies will be taken into account by the courts in the event of a negligence claim being brought.

${ }^{122}$ Reynolds $v$ Times Newspapers Ltd [2001] 2 AC 127 (HL).

123 Section 4(6) of the Defamation Act 2013 abolished the Reynolds privilege and installed its place (s 4(1)) a defence of publication on a matter of public interest. As to this change, see LK Yang, 'Reynolds privilege transformed' (2014) 130 LQR 24.

${ }^{124}$ In Flood v Times Newspapers Ltd [2012] UKSC 11; [2012] 2 AC 273, 300 [79] Lord Phillips of Worth Matravers PSC spoke in terms that suggest that he regarded these words as synonyms. However, in Jameel (Mohammed) v Wall Street Journal Europe Sprl [2006] UKHL 44; [2007] 1 AC 359, 383 [55] Lord Hoffmann appeared to distinguish them.

${ }^{125}$ As introduced, the Bill that became SARAH would have added to the end of s 4 the words 'and without regard to the person's own safety or other interests'.

${ }^{126}$ HC Deb, 21 July 2014, vol 566, col 1193. 
Section 4, like sections 2 and 3, is phrased in mandatory language ('must'). The following requirements must all be satisfied before it applies. The person in issue must: (1) have acted 'heroically' (2) in intervening in an 'emergency' (3) 'to assist an individual in danger'. It is not required that the claimant be the person assisted. Thus, if a defendant injures a claimant in the course of rescuing a third party, section 4 may well apply.

Section 4 is riddled with oddities, which suggest, individually and in combination, that it was not properly thought through. Five will be mentioned. The first concerns motive. The word 'heroically' makes the motive of the person in question relevant. Suppose that A inadvertently saves B from danger. Because A was not aware of the dangerous situation, A cannot be said to have acted 'heroically' in these circumstances. So unless the person was virtuously motivated, section 4 will not apply. At first glance, this appears to be a satisfactory position. But it follows that a person who rescues another only because he is under a legal duty to do so will not benefit from section 4. It might be that it is difficult, therefore, for professional rescuers in particular to take advantage of section 4. This cannot have been intended by the legislature. The second oddity is that there must actually be an emergency before section 4 will be triggered. Hence, it seems that section 4 will not apply where a person in issue has proceeded on the basis of mistaken belief as to the existence of an emergency, even if the belief is reasonable. A third peculiarity is that section 4 will not apply where only property is endangered. This is because section 4 speaks of an 'individual' in danger. Given that one of the goals of SARAH is to encourage volunteering, which might be taken to include any selfless act, it is strange that section 4 does not apply to people who take steps to protect the property of others. Fourth, it is doubtful whether section 4 adds anything to section 2. A person who acts heroically will necessarily be 'acting for the benefit of society or any of its members', while the converse is not necessarily the case. In this regard, observe that section 4 seems to be narrower than section 2 also in terms of the types of person who 
can benefit from it. It is hard to see how non-natural persons could act heroically while, as discussed above, ${ }^{127}$ it is likely that artificial persons can invoke section 2 . It is true that section 4 distinguishes between 'person' and 'individual'. The implication is that 'person' thereby includes non-natural persons. Be this as it may, it is nevertheless hard, for the reason that has just given, to see how a non-natural person could benefit from section 4. Finally, section 4 might apply to persons who act with gross negligence. Suppose that $\mathrm{C}$ is in danger of drowning and $\mathrm{D}$ attempts to aid $\mathrm{C}$ even though professional lifesavers already are in the process of rescuing $\mathrm{C}$ and have the matter well in hand. D injures $\mathrm{C}$ in the course of his bungling rescue efforts. Section 4 would prima facie apply. It is unsurprising that the Fire Brigades Union, in giving evidence to Parliament, described section as 'potentially a very dangerous clause'. ${ }^{128}$

The legislature obviously hoped that section 4 would encourage heroism, or at least intended that section 4 would ensure that tort law does not discourage it. The legislature's efforts in this regard are misguided. It is doubtful that people who are confronted by emergencies will be influenced by the law. Finding oneself in an emergency will often mean that the law is the last thing that is likely to enter one's mind. Furthermore, it is questionable whether it is sensible to encourage heroic acts, at least by non-professional rescuers. Such rescuers are liable to make matters worse. They may simply find that they require rescuing themselves and thereby compound the problems faced by professional rescuers.

Unlike sections 2 and 3, it is doubtful whether section 4 changes the law. ${ }^{129}$ It has long been established that the fact that a person a person was carrying out a rescue is relevant to the determination of both negligence ${ }^{130}$ and contributory negligence. ${ }^{131}$ As Nicholas McBride

\footnotetext{
127 See the text accompanying $n$ 91, above.

128 PBC Deb, 4 September 2014, col 21 (Mr Wrack).

129 The government considered that s 4 restates the common law: PBC Deb, 9 September 2014, col 62 (Mr Vara).

130 'The saving of life or limb justifies taking considerable risk': Watt v Hertfordshire County Council [1954] 1 WLR 835 (CA) 838 (Denning LJ). See also at 838 (Singleton LJ).
} 
and Roderick Bagshaw succinctly put it: 's 4 adds nothing to the law: the same principle has long been given effect to by the courts., ${ }^{132}$

\subsection{Coda}

This section has analysed the provisions that constitute SARAH. The analysis has been lengthy, but this was warranted given that SARAH, still in its infancy, has not yet been the subject of extended consideration, judicial or academic. It was argued, contrary to prevailing opinion, that sections 2 and 3 change the law. However, the changes are admittedly unlikely to be of great significance. Ultimately, these sections (like section 4) merely require the court to have 'regard' to certain matters. This section of the article additionally showed that the significance of SARAH is not confined, as appears to be widely thought, to personal injury cases. SARAH is not even confined to tort cases. SARAH potentially applies to much private law litigation.

Before proceeding, it is worth observing that SARAH is a very modest development relative to the experience in certain other jurisdictions. Consider, in particular, the situation in relation to Australia. In several Australian jurisdictions, legislation enacted at the start of the twenty-first century in order to tackle an 'insurance crisis' ${ }^{133}$ provided for, relevantly, robust defences for volunteers ${ }^{134}$ and Good Samaritans who intervene in an emergency. ${ }^{135}$ The details of these defences differ very considerably from jurisdiction to jurisdiction. This is not

\footnotetext{
131 'The law recognises that a rescuer may, in effecting or attempting to effect a reduction of risk to others, imperil of his own life and limb: and the greater the risk to others that he is trying to avert, the greater the imperilment to his safety the law will accept as reasonable': Tolley v Carr [2010] EWHC 2191 (QB); [2011] RTR 7, [22] (Hickinbottom J).

132 McBride and Bagshaw, above n 14, 261 (footnote omitted).

${ }^{133}$ Leading treatments include P Cane, 'Reforming Tort Law in Australia: A Personal Perspective' (2003) 27 MULR 649; H Luntz, 'The Australian Picture' (2004) 35 VUWLR 879; B McDonald, 'Legislative Intervention in the Law of Negligence: The Common Law, Statutory Interpretation and Tort Reform in Australia' (2005) 27 Syd LR 443.

134 See, e.g., Civil Liability Act 2002 (NSW), s 61.

135 See, e.g., Civil Liability Act 2002 (NSW), pt 8.
} 
the place to investigate them. They have been treated in detail elsewhere. ${ }^{136}$ The point to take away for present purposes is that, whatever one thinks of SARAH, the Parliament at Westminster acted as a paragon of caution and moderation relative to its Australian counterparts.

\section{Restating the common law}

Parliament is increasingly prone to restate the common law. Certain of the provisions of the Compensation Act 2006 mirror the common law, as discussed above. ${ }^{137}$ The same tendency is manifested in the Defamation Act 2013, which was also canvassed earlier. ${ }^{138}$ Section 2 of that Act, in laying down a defence of truth, simply repeats the common law. ${ }^{139}$ Section $4(3)$ of the same statute replicates the reportage defence. ${ }^{140}$ The conclusion reached in the preceding part of this article is that section 4 of SARAH reiterates the common law. ${ }^{141}$ This now pronounced disposition on the part of the legislature to restate common law rules, ${ }^{142}$ which is not confined to tort law but which can be seen throughout the law generally, has not received sustained academic treatment. It warrants a few words in this article.

There are several reasons why the legislature may want to restate the common law. ${ }^{143}$ One objective of provisions that replicate the common law is to increase the public profile of a given rule or set of rules. This reason was important in relation to SARAH. The then

\footnotetext{
136 See, e.g., M McGregor-Lowndes and L Nguyen, 'Volunteers and the New Tort Reform' (2005) 13 TLJ 1.

137 See the text accompanying $\mathrm{n} 5$, above.

138 Discussed at the text accompanying nn 6-14, above.

139 Technically, s 2 repeats the common law defence of truth as modified by s 5 of the Defamation Act 1952. It should also be mentioned that s 2 prefers the label 'truth' to that of 'justification'.

140 '[Section 4(3)] sets out a more or less consonant version of the mainstream of the common law doctrine': Mullis, Parkes and Busuttil, above n 13, [15.15].

141 See the text accompanying nn 129-132, above.

142 This disposition is not unique to the Parliament at Westminster. Certain of the Australian statutes mentioned above (see the text accompanying nn 133-136) contain many provisions that do nothing more than replicate the existing law: see McDonald, above n 133, 460-463.

143 Cf Lord Lloyd of Berwick's remark made in the course of the Parliamentary debates regarding SARAH that SARAH was a 'flagrant misuse of the legislative process' because it did not 'make new law': HL Deb, 15 December 2014, vol 589, col 15.
} 
Lord Chancellor said that SARAH 'sends a signal to our judges and a signal to those thinking about trying it on—by bringing a case in the hope that it will not be defended—that the law is no longer on their side.' ${ }^{144}$ He added that 'above all' ${ }^{145}$ this was SARAH's purpose. What matters is that 'there is clear visibility of the law' ${ }^{146}$ It hardly needs to be mentioned, of course, that legislation is a particularly ineffective means of accomplishing this goal given that the details of statutes will rarely, if ever, be a matter of public knowledge. Additional reasons why the legislature might wish to restate the common law include a desire to dispel doubt as to whether a given rule exists, to articulate more clearly and succinctly a common law rule the contents of which can be understood only by reading numerous cases alongside each other, and a concern to freeze the common law at a given point in time and thereby stifle further development. None of these additional reasons seemed to be important in relation to SARAH.

What disadvantages attend provisions that merely restate the common law? One obvious problem is that it will often be unclear whether the legislature has restated verbatim the common law or whether it has changed it in some way. Creative arguments will be advanced in relation to what are at first glance provisions that restate the law in support of the conclusion that some subtle difference now exists between the common law and a given statutory provision. There will always be scope for debates on this score given the nature of the common law. The common law is a complex amalgamation of judicial propositions uttered by many different judges at various points in history. It is impossible, therefore, for the common law to be perfectly captured in the terse statutory language. Inevitably, something will be lost in the translation. This is no doubt part of the reason for the frequently

\footnotetext{
144 HC Deb, 21 July 2014, vol 566, col 1187.

145 ibid, col 1191.

146 ibid, col 1189.
} 
made remark that it is wrong to interpret judicial remarks as though they were part of a statute. ${ }^{147}$

Another major problem is that when legislation restates the common law, it might be uncertain whether the legislation provides for an exclusive regime or whether it operates in tandem with the common law rules that it replicates. ${ }^{148}$ It will often be important to know if there are two bodies of rules - one statutory and one common law - or just a single set. For example, if restating legislation sits alongside the common law, ongoing development of the common law might be permissible with the result that two initially matching sets of rules may grow apart while this will obviously not be possible if the statute operates exclusively. This second problem can be avoided if the legislature expressly states (or otherwise makes it clear) that the common law is preserved or abolished. ${ }^{149}$ However, statutes are often enacted that contain no such provisions, as is the case in relation to SARAH, for example. Furthermore, if the legislature attempts to address this second problem, it may unwittingly introduce other difficulties, at least when it preserves the common law. ${ }^{150}$ For instance, a clause that expressly preserves a common law rule is likely to cause difficultly if the rule is not identified with precision or the rule is unsettled. In this event, questions will arise as to which rule has been saved.

For the foregoing reasons, provisions that restate the common law are prima facie thoroughly undesirable. However, if the legislature chooses to restate common law rules, how should it go about doing so? There are a few basic guidelines that should be followed in this

147 See, e.g., Makdessi v Cavendish Square Holdings BV [2015] UKSC 67; [2015] 3 WLR 1373, 1387 (Lord Neuberger of Abbotsbury PSC and Lord Sumption JSC).

${ }^{148}$ For discussion, see A Burrows, 'The relationship between common law and statute in the law of obligations' (2012) 128 LQR 232, 236-240.

149 For an example of express abolition, Occupiers' Liability Act 1957, s 1(1). An excellent illustration of implicit abolition is the Law Reform Contributory Negligence Act 1945, s (1), which removes, implicitly but nonetheless clearly, the rule that contributory negligence on the part of the claimant results in the complete failure of his cause of action.

${ }^{150}$ For discussion, see R Munday, 'Legislation that would "Preserve" the Common Law: The Case of the (Hearsay) Declaration of Intention’ (2008) 124 LQR 46, esp 52. Munday’s conclusion (at 71) is that preservation clauses are 'either best avoided altogether or only employed when the relevant rule of common law can be exactly identified and all risk of its being further developed is safely passed.' 
regard in order to minimise disruption. First and foremost, the legislature should not scatter provisions that replicate a given branch of the common law across various statutes. Doing so dramatically decreases the accessibility of the law, which frustrates one of the possible aims of restating the common law. Furthermore, in the interests of keeping things as straightforward as possible, the legislature should not restate the same rule on multiple occasions. Finally, the legislature is advised to provide expressly that the common law that is being restated is abolished. Doing so will promote simplicity and guard against the possibility that surviving common law may drift apart from the legislation.

\section{Conclusion}

SARAH is the latest addition to a complex legislative machine that is designed to address the supposed compensation culture. This article has argued that, contrary to prevailing views, certain of SARAH's provisions change the law, although, overall, the changes, admittedly, are unlikely to have a particularly large impact in practice. Attention has also been drawn to the fact that SARAH is definitively not a personal injury statute nor even a tort statute. Its provisions apply much more broadly, which is an important fact about the Act that has so far gone unnoticed.

SARAH spawns a series of important questions regarding the nature of legislation. One such question, with which this article engaged, is whether it is advisable for legislation to be enacted that restates the common law. It was suggested that such legislation is generally undesirable. Many other significant cognate issues remain unexplored. These include whether, given the growth of legislation in tort law, the courts should be more reluctant than they were previously to develop the law. This and other such issues need to be attended to on another day. 